\title{
Modelling soil erosion and deposition within a Mediterranean mountainous environment utilizing remote sensing and GIS - Wadi Tlata, Morocco
}

\author{
Hao Chen, Worcester, Abdelkader El Garouani, Fès, \\ Laurence A. Lewis, Worcester
}

\section{Introduction}

The removal of permanent vegetation has accelerated erosion and deposition in many stream basins within the Mediterranean region. Accelerated erosion, resulting largely from overland flows (TRIBAK 2000), along with deposition increases in low lying sinks, especially reservoirs, results in land degradation. The tributary steam basin of the Wadi Tlata in northeastern Morocco exemplifies these phenomena. Due to agricultural and grazing activities which altered the area's vegetation cover, accelerated erosion and deposition is being experienced throughout the catchment. The spatial alteration of the wadi's erosional/depositional balances has clear impacts on the economic potential of the area.

This study's aim is to gain insights applicable in assessing land degradation occurring in similar Mediterranean environments. In addition, this investigation's approach illustrates how a relatively quick assessment of an area's erosional and depositional properties can be determined even in areas with minimal data. The investigation utilizes space imagery over a 15 year period (1987-2002) and analyzes these data within a geographical information system (GIS). Based on the outcomes of the analysis, an ordinal ranking of the spatial properties of erosion and deposition is obtained. This ranking can be used to determine critical areas within the catchment needing implementation of conservation practices to curtail land degradation.

\section{Background and method}

\subsection{Study area}

The $123 \mathrm{~km}^{2}$ of the Wadi Tlata Catchment, located in northeastern Morocco, has a generally northwest to southeast orientation (Fig. 1). The basin has a rugged topography, elevations range from 1,373 in the northwest to 560 meters at the stream's mouth. The dominant underlying bedrock, tertiary marls (LEBLANC 1979), produces soils easily eroded when exposed by human activities. Given the area's relief and climate, occasional intense winter rainfall and a paucity of precipitation during the hot summer months, when vegetation is disturbed, the potential for accelerated erosion is high. These physical attributes, along with an average population density of $76 / \mathrm{km}^{2}$ and ubiquitous agricultural activities, result in slopes largely denuded of their natural ground cover.

\subsection{Methodology}

This study utilizes space imagery and field data to determine the topography, land use, and ground cover. These data are then processed and the spatial distribution of soil loss and sedimentation are estimated using a RUSLE (LEWIS et al. 2005) and sedimentation (flow) model within a GIS framework (Fig 2). The extraction of the information sets (e.g. land use) utilized topographic maps, field work, and satellite imagery. The development of the digital elevation model (DEM) (derived from a topographic map with $10 \mathrm{~m}$ contours) and digitization of the data layers were created using Arc View. The analysis of these data sets, including image processing and the modelling of soil loss and sedimentation utilized Idrisi (Fig. 2).

Most prior studies concerning soil loss based on the USLE/RUSLE (Universal Soil Loss Equation/Revised Universal Soil Loss Equation) model developed by WischmeIER and SMITH (1978) and refined by RENARD et al. (1991) do not examine the related process of deposition (BonN 1998; Dialo 2000; RenARD et al. 1997; WischMEIER 1976) since RUSLE's conceptualization only permits soil loss to be estimated. Some authors have asserted the possibility of identifying deposition zones using accurate DEMs (Mitasova et al. 1996; Moore \& Burch 1986). Previously, VAN Rompaey et al. (2001) integrated soil loss and deposition into a single model based on RUSLE. However, their model requires the sediment delivery ratio which varies within catchments and is rarely known for most areas. Others (FERnAndez et al. 2003 and Mutua et al. 2006) have extended RUSLE to also estimate sediment yield. The approach presented here directly integrates RUSLE's output data into a flow model which allows net soil loss and deposition to be accessed within a GIS framework without additional data requirements. This represents an extension of the incorporation of RUSLE into a GIS framework by LEWIS et al. (2005).

Space imagery analysis was used to determine the two factors considered to strongly affect erosion and deposition: land use and land cover. Four images were analyzed (Spot HRV: 15 Nov. 1994 and three Landsat TM: 9 Feb. 1987; 25 Apr. 2000; and 24 Oct. 2002). It would have been better to have satellite coverage for identi- 


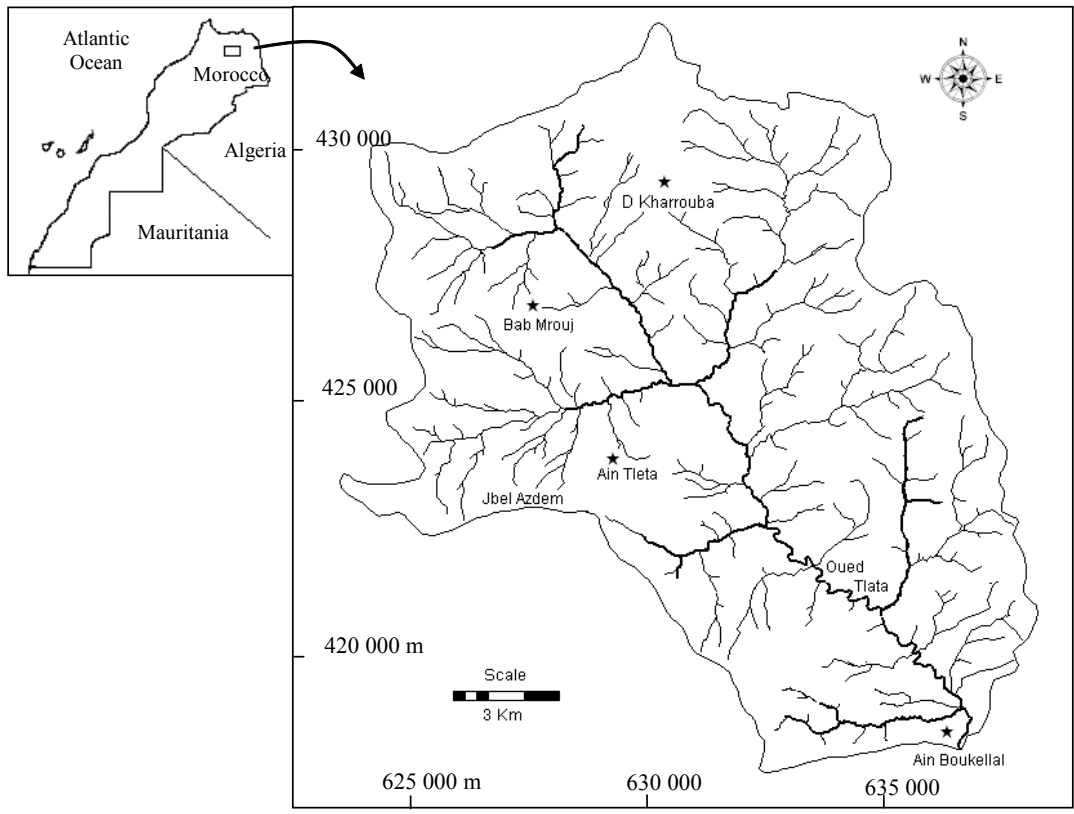

Fig. 1: Location of study area in Morocco

Lage des Untersuchungsgebietes in Marokko

Localisation de la zone d'étude au Maroc

Cartography: A. El Garouani, L.A. Lewis

cal months, but this was not possible. While the months vary, identification of land use and land cover from each image was possible. These results were then used to model soil loss and deposition in the GIS models.

\subsubsection{Utilization of satellite images for land cover/land use data}

A four step procedure was undertaken to obtain data on land cover and land use from the satellite imagery. First, the visual interpretation allowed identification of broad classes of land cover. Second, the broad «visual» groupings were refined by an unsupervised classification based on their spectral signatures. Third, post-classification filtering was undertaken to remove likely errors from the data. Finally, a temporal analysis was initiated to determine the land cover and land use changes that took place during the study period. The land cover/land use data were inputs into the RUSLE model. The output from this model and the SEDIMENTATION module permitted the examination of spatial and temporal patterns and gave insights into soil loss and sedimentation totals.

A. Visual interpretation. Forest areas were delimited based on the satellite images' color composition. The forest areas were then classified as «natural protected» or «afforested» based on previous field visits. Differentiation between «bare ground areas» and «badland zones» was made in a similar manner. Whereas the classification of forest, bare ground and badland areas is considered to have a low error ratio, cultivated lands are less certain. It was hard to differentiate the various types of cultivated land. Only where olive tree plantations were visible was error probability considered small in identifying the cultivated land type.

B. Unsupervised classification. In the next step, an unsupervised classification of the visually determined groupings was undertaken. Within each visual grouping, pixels were grouped on the basis of similar spectral signatures (JAIN et al. 1999). Ten classes of specialized land cover, based on the known characteristics of the visual classification were chosen in this initial grouping. Next, several iterations of this initial grouping were performed during which arrangements and groupings of the classes were refined to create more homogeneous and better differentiated groups. This process results in classes that reflect real land use. To improve these results, it was necessary to define several subclasses, with slightly different spectral properties. For example, the spectral properties of identical forest 


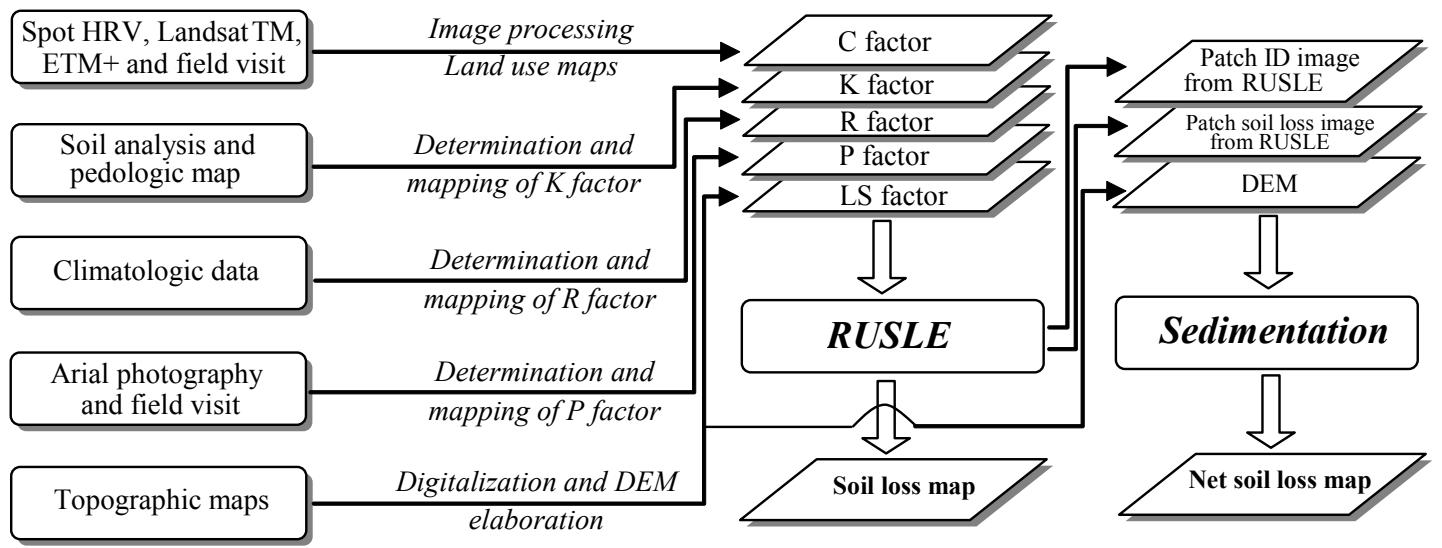

Fig. 2: Schematic presentation of the methodology

Schema der Methodologie

Schéma de la méthodologie

classes vary appreciably according to slope exposure. It was possible to identify two subclasses (forest on the slope exposed to the south and forest on shaded slopes). Consequently, by specifying the spectral definition of each corresponding class, classification quality was appreciably improved. Using this logic it was possible to identify the following classes: badlands, arable lands, and permanent vegetation (protected natural forest and reforestation).

The classes were then refined to decrease within variability. In certain cases, where land covers are known, specific land cover can be isolated by carrying out a simple thresholding of the numerical values in either one (monospectral) or several (multispectral) spectral bands. A class of objects is defined by a range of values (i.e. all pixels with numerical values that correlate with a given known ground cover on a specific image). Particular use was made of the «red» TM3 band as it allows for discrimination between plants species. For example, the higher TM3 band values were found to represent protected forest cover. These results along with utilization of the Normalized Difference Vegetation Index (NDVI), allow differentiation of land cover/land use into six classes: badland/degraded, annual cereal crop lands, arable lands with trees, olive trees, reforested areas, and natural forest areas.

C. Post-classification filtering. Finally, to develop the tables of land use and ground cover, it was necessary to refine the results obtained from the previous classification procedures. For this purpose, various filtering techniques were implemented (Fig. 3). Attention was given to single isolated pixels, pixels that were not classified, and pixels that were clearly misclassified. These problem areas often occurred along boundary conditions including two different vegetation covers or land use classes as well as along the catchment divide.

Single isolated pixels were treated as errors as land use units in the study area are not this small. To homogenize isolated pixels a filtering technique was used to remove all one and two pixel islands and most three pixel islands. The only three pixel islands that the filtering technique did not remove were those clustered in a corner shaped configuration (Fig. 3a). The technique used to remove these isolated pixel islands was a 3-by-3 moving window. By moving the window pixel-by-pixel across the entire image surface, all islands could be located. Location of isolated pixels was accomplished through a two-stage sequential filtering process. The first stage exploits a relaxed filtering approach with the isolation threshold set at $87.5 \%$. This means a pixel with a certain class will be considered isolated only if it is surrounded fully by any other class or surrounded by a single dominant class which accounts for $87.5 \%$ of the neighboring pixels, i.e. 7 out of 8 in a 3-by-3 neighborhood (Fig. 3b). Once an isolated pixel is identified, it is merged into the dominant neighboring class by converting its original class value to the value of the dominant class (Fig. 3c). The second filtering step utilizes an isolation threshold of $100 \%$. This step deals with central pixels that are completely surrounded by a different, but homogenous class (the situation of single pixels being surrounded by two or more classes were treated in step 1) (Fig. 3d). 


\begin{tabular}{|c|c|c|c|}
\hline 1 & 1 & 1 & 1 \\
\hline 1 & 1 & 2 & 1 \\
\hline 1 & 2 & 2 & 1 \\
\hline 1 & 1 & 1 & 1 \\
\hline
\end{tabular}

(a)

\begin{tabular}{|l|l|l|}
\hline 1 & 2 & 1 \\
\hline 1 & 2 & 1 \\
\hline 1 & 1 & 1 \\
\hline
\end{tabular}

(b)

\begin{tabular}{|l|l|l|}
\hline 1 & 2 & 1 \\
\hline 1 & 1 & 1 \\
\hline 1 & 1 & 1 \\
\hline
\end{tabular}

(c)

\begin{tabular}{|l|l|l|}
\hline 1 & 1 & 1 \\
\hline 1 & 2 & 1 \\
\hline 1 & 1 & 1 \\
\hline
\end{tabular}

(d)

Fig. 3: Filtering techniques: a) three-pixel corner configuration, b) isolated pixel surrounded by $87.5 \%$ of dominant class, c) conversion of original class to dominant class, d) isolation threshold of $100 \%$

Filterungstechniken: a) Anordnung einer 3-Pixel-Ecke, b) isolierter Pixel, umgeben von 87.5\% Pixel der dominierenden Klasse, c) Umwandlung der Originalklasse in die dominierende Klasse, d) zu 100\% isolierter Grenzwert Techniques de filtrage: a) configuration en «three-pixel corner», b) pixel isolé entouré par $87.5 \%$ de classe dominante, c) conversion de classe originale en classe dominante, d) seuil d'isolement de 100\%

D. Combination of images: The multi-temporal analysis. One principal advantage of utilizing satellite images over an extended time frame is that ground cover and vegetation changes over time can be deciphered. The approach presented in this paper permitted a reliable ordinal ranking of soil loss and deposition for the study area, a location with a minimal environmental data base. Four land use/ land cover maps (for each satellite image) for the 1987 to 2002 period were developed. These land cover/land use data are inputs into the RUSLE and SEDIMENTATION modules. The outputs from these models permit the examination of the spatial and temporal patterns and the soil loss and sedimentation estimates.

\section{Modelling soil loss and deposition}

\subsection{Determination of RUSLE input parameters}

The RUSLE model is conceptualized as:

$$
\mathrm{A}=\mathrm{R} * \mathrm{~K} * \mathrm{~L} * \mathrm{~S} * \mathrm{C} * \mathrm{P}
$$

where

$\mathrm{A}=$ average annual soil loss (tons $\mathrm{ha}^{-1}$ year $\left.^{-1}\right)$,

$\mathrm{R}=$ rainfall erosivity factor $\left(\mathrm{MJ} \mathrm{mm} \mathrm{ha} \mathrm{mear}^{-1}\right)$,

$\mathrm{K}$ = soil erodability factor (tons ha $\mathrm{MJ}^{-1} \mathrm{~mm}^{-1}$ ),
$\mathrm{L}$ = slope length factor $(\mathrm{L} / \mathrm{L})^{\mathrm{m}}$,

$\mathrm{S}=$ slope steepness factor (percent),

$\mathrm{C}=$ vegetation cover management factor (dimensionless), and

$\mathrm{P}=$ supporting (conservation) practices (dimensionless) (REnard et al. 1997).

The study's R value (56.3) was based on the formula of RANGO \& ARNOLDUs (1987) and derived using 1977-1994 data from the Ain Boukalla weather station situated within the Wadi Tlata. $\mathrm{K}$ values were derived using the WischMeIER nomogram (WISchMEIER \& SMITH 1978), a pedological map and the area's infiltration properties (TriBaK et al. 2006). The $\mathrm{K}$ factor for the river basin's soils ranged from 0.22 to 0.46 . The LS factor was computed using GIS software (LewIS et al. 2005). The crop cover factor $(\mathrm{C})$ was calculated using the satellite images, as well as ground truth observations. The values assigned to land cover ranged between 0.08 for natural protected forest to 0.75 for poorly vegetated badlands. These values are based on the previous calibration of this factor for the local agricultural system (KALMAN 1967). The P factor value of 1 (no conservation) was assigned for the whole area since little conservation is practiced in the study area, and where practiced, it is poorly implemented. 


\subsection{Estimation of soil loss}

After determining the RUSLE input parameters, soil loss was estimated using the RUSLE module (LEWIS et al.2005). The execution of the module requires thresholds for slope, azimuth and slope length. The maximum threshold slope length is the distance beyond which overland flow becomes concentrated. RUSLE recommends lengths less than 122 meters (RENARD et al. 1997). For the approach presented here, thresholds of 5 degrees for slope, 10 degrees for azimuth and $100 \mathrm{~m}$ for maximum slope length were utilized. These values are reasonable for the topographic characteristics of the wadi.

\subsection{Estimating net soil loss and deposition}

One limitation of RUSLE's conceptualization is that its application to any land unit must result in soil loss; it cannot predict deposition. Yet clearly within many agricultural fields and river basins, deposition occurs. The reason RUSLE only estimates soil loss is that it views soil loss in a static manner. Soil loss is estimated for all areas based on their R, K, L, S, C, P parameters. The downslope movement of soil loss from one area (patch) to another is not conceptualized within RUSLE. By incorporating the RUSLE algorithm into a GIS framework, it is possible to examine the spatial down slope movement of soil loss and from these movements determine net soil loss and deposition. Net erosion or deposition for a given area is determined in the following manner when applying the SEDIMENTATION module software: determination of patch soil loss, establishment of direction of soil movement and calculation of proportional soil loss.

First, soil loss for each patch (a constructed homogeneous polygon with regard to slope aspect, slope, land cover, conservation practice, erodability, and erosivity) within the river basin is determined (LEWIS et al.2005). Next, the average elevation for each patch is identified. This is derived by averaging the highest and lowest elevations in each patch. Then the river basin's highest elevation is located. The direction of soil movement is established by taking the relative elevation differences between contiguous patches into account. The amount of soil loss that moves into the surrounding lower patches is assumed to be proportional to the length of the common boundary between the higher patch and the lower patches (EASTMAN 2006). Next, the net soil loss and deposition in all the lower patches is calculated. The proportional RUSLE soil loss moving from the higher patch is compared to the RUSLE soil loss derived for the lower patch. For example, the proportional soil loss of Patch A (the higher one) to lower patch B is $1 \mathrm{Mg} \mathrm{yr}^{-1}$. Patch B's initial RUSLE computed soil loss is $3 \mathrm{Mg} \mathrm{yr}^{-1}$. Thus, the net soil loss of Patch B is calculated by the SEDIMENTATION module as the difference between the amount of sediment trans- ported into the patch and the patch's RUSLE soil loss value. In the previous example, $3 \mathrm{Mg} \mathrm{yr}^{-1}$ (B) $-1 \mathrm{Mg}$ $\mathrm{yr}^{-1}$ (A) results in a net soil loss for Patch B of $2 \mathrm{Mg} \mathrm{yr}^{-1}$ (Fig. 4a). Similarly, if Patch C located downslope from Patch B, has an estimated soil loss of $2 \mathrm{Mg} \mathrm{yr}^{-1}$, its net deposition will be $1 \mathrm{Mg} \mathrm{yr}^{-1}$ (Fig. 4b).

\section{Results and discussion}

\subsection{Land use and land cover changes}

The multi-temporal analysis results of the four satellite images (1987-2002) using visual comparison and cross tab analysis revealed the following changes in the six land use and land cover classes (Table 1):

1: badlands/degraded lands increased in areal extent in each time period;

2: cultivated areas of largely cereal crops decrease in areal extent in each time period;

3: lands under olive cultivation generally increased; 4: reforested land, which are lands that have degraded too much for cultivation, increase slightly;

5: mixed farmlands (comprised of cereal crops and tree crops) showed an increasing trend over the time period; and

6: areas of natural forest remained relatively stable.

Thus, reforested areas and areas with natural shrub forest were relatively stable in terms of cover during the 15 year period; badlands and degraded lands almost doubled in areal extent and tree crops expanded while areas solely farmed in cereals declined. Nevertheless, farmlands in cereal production remained the dominant land use.

\subsection{Soil loss estimates}

After land use was determined, estimates of average annual soil losses for each ground cover were computed using RUSLE. These results for each image are presented in Table 2. Soil loss estimates range between $58 \mathrm{Mg} \mathrm{ha}^{-1} \mathrm{yr}^{-1}$ in the protected natural open forest areas (1994) to $355 \mathrm{Mg} \mathrm{ha}^{-1} \mathrm{yr}^{-1}$ in the degraded badland/degraded areas (1987). Areas under annual crop cultivation experience the highest soil losses of the farmed land use classes (81-83 $\mathrm{Mg} \mathrm{ha}^{-1} \mathrm{yr}^{-1}$ ) (Table 2). Besides high RUSLE soil loss estimates for all time periods and all land covers, the standard deviation for all land use classes is large (Table 2). This high variability is largely explained by the wide range of slope values existing within each land use class.

The spatial patterns of soil loss within the river basin did not differ greatly over the 15 year study period. Given this finding, the average soil loss values for each land use are used to illustrate the spatial pattern of estimated soil loss for the catchment (Fig. 5). Overall the lowest soil loss values are found on the gentlest 

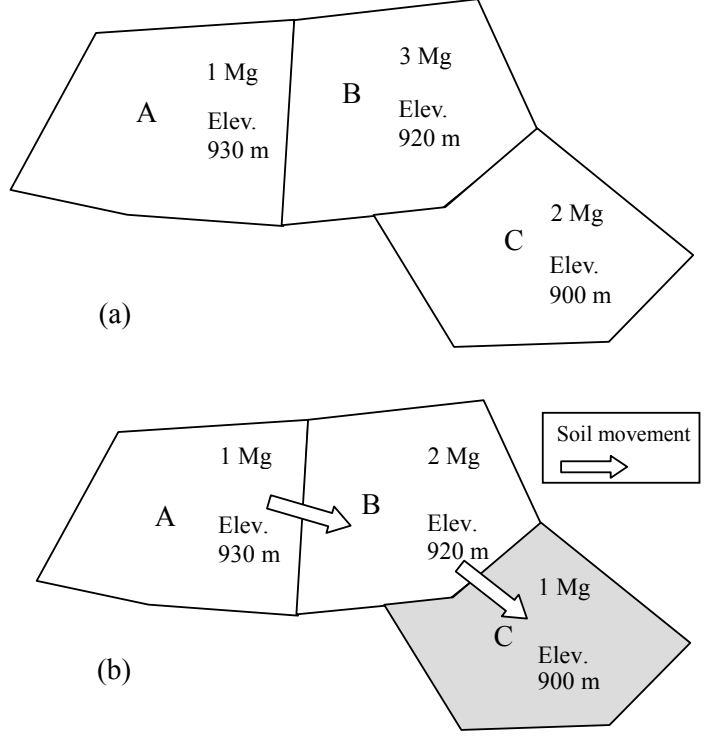

Fig. 4: a) Patches with estimated RUSLE soil loss values, b) net soil loss/deposition (shaded grey)

a) RUSLE-Werte des Bodenverlustes, b) Nettobodenverlust und -ablagerung (grau schattiert)

a) Valeurs estimées d'érosion du sol, b) perte et dépôt de sol nets (gris ombragé)

slopes, especially along the valley bottoms. The highest values largely reflect the combination of land cover and slope. Soil erodability properties have a slight impact. Neither the rainfall nor conservation factors contribute to the spatial pattern as the rainfall factor varies only slightly in the basin and conservation is not practiced throughout the wadi.

The exceptionally high average annual soil losses calculated are not surprising given the inability of RUSLE to incorporate downslope movement of soils from one area to another. Soil loss in RUSLE is evaluated for each homogenous land unit (patch) independently. The model cannot account for downslope deposition resulting from breaks in the slope, denser ground cover, or other factors that mitigate soil loss. Thus, RUSLE must overestimate actual soil losses whenever soil movement between fields or areas exists. This conclusion is justified from the derived soil loss values obtained in areas cultivated under annual crops. These values are so high $\left(82 \mathrm{Mg} \mathrm{ha}^{-1} \mathrm{yr}^{-1}\right)$ that if accurate, agricultural activities could not have been sustained over the 15 year study period. In all likelihood, the soil resource would have been completely degraded.
Applying the SEDIMENTATION module to RUSLE allows for net soil loss for each patch to be estimated. This approach should result in a more accurate assessment of net soil loss. Once downslope movement of soil is incorporated into the estimates, soil losses are significantly less (Table 3). Of particular interest is that three classes of land cover (annual crops, mixed farmlands, and reforestation) based on average values flip from an erosional mode into a depositional dynamic. In addition, areas under olive tree cultivation have their soil losses reduced from an unsustainable estimated (RUSLE) average soil loss of $77 \mathrm{Mg} \mathrm{ha}^{-1} \mathrm{yr}^{-1}$ to $0.5 \mathrm{Mg} \mathrm{ha}^{-1} \mathrm{yr}^{-1}$. Both the badland and natural open forest classes remain in the erosion mode. The open forests and badland classes with generally steep slopes minimize depositional potential.

Examination of the standard deviations of the net soil losses (Table 3) give further insights into the soil dynamics occurring in the catchment. The land use classes of annual crop cultivation and mixed farmlands occupy a large proportion of the river basin. In the areas where these cultivations occur on moderate and steep slopes, the data indicate these are zones of excessive erosion. But when these farming activities occur on the plains and valley bottoms, they experience net deposition. The net soil loss map (Fig. 6) shows that in the eastern and southeastern portions of the basin, areas where highly erodible soils derived from marls and sandy marls are found (see TRIBEK 2000 for details of soil properties), net soil losses of $50 \mathrm{Mg} \mathrm{ha}^{-1} \mathrm{yr}^{-1}$ occur. Given that these zones occupy approximately 1150 ha or $9.5 \%$ of the basin, the soil loss data indicate these areas must be degrading and are likely to experience declining yields in the near term or eventually go out of production unless interventions occur shortly.

\subsection{Discussion}

A comparison of the results with previous findings (AL Karkouri 2003; Dhman 1994; El Garouani et al. 2003; Heusch 1970; RahHou 1999) highlights the dampening effect that a dual focus on erosion and deposition has on catchment erosion risk assessment. An overall decrease occurs in the erosion rates of a river basin. Although the studies mentioned above agree that a high erosion risk exists in mountainous areas in Mediterranean regions, this paper indicates that this could only be confirmed for the eastern sections of Wadi Tlata.

The multi-temporal analysis of land cover and land use indicates that the erosion risk has increased on moderate to steep slopes in the eastern portion of Wadi Tlata. These high risk areas comprise almost 10\% of the basin's area. Given the high soil loss of these areas, changes in the farming system to better reflect the environmental properties of the basin need to be 


\begin{tabular}{|lccccc|}
\hline Land use classes & 1987 & 1994 & 2000 & 2002 & $\begin{array}{c}\text { Average \% of } \\
\text { change } \\
(1987-2202)\end{array}$ \\
\hline Badlands (degraded land) & 6.9 & 7.8 & 10.1 & 11.5 & 67.5 \\
Cereal (annual) crops & 92.9 & 87.6 & 80.4 & 74.8 & -19.4 \\
Mixed farmlands & 10.6 & 9.9 & 16.6 & 19.7 & 85.0 \\
Olive trees & 7.3 & 11.0 & 10.4 & 11.3 & 53.8 \\
Reforestation & 1.9 & 2.0 & 2.1 & 2.1 & 11.8 \\
Natural protected forest & 1.1 & 1.4 & 1.1 & 1.3 & 8.7 \\
\hline
\end{tabular}

Tab. 1: Relative changes in land cover over a 15 year period according to land use class. Land cover values for each time period are in $\mathrm{km}^{2}$.

Relative Veränderung der Landnutzung, nach Landnutzungsklassen, während einer Zeitspanne von 15 Jahren. Die Werte der Landnutzung für jeden Zeitraum sind in $\mathrm{km}^{2}$ angegeben.

Changement relatif de la couverture du sol sur une période de 15 ans selon la classe d'utilisation du sol. Les valeurs relatives à la couverture du sol pour chaque période sont en $\mathrm{km}^{2}$.

\begin{tabular}{|lccccccccc|}
\hline & \multicolumn{2}{c}{1987} & \multicolumn{2}{c}{1994} & \multicolumn{2}{c}{2000} & 2002 & $1987-2000$ \\
\hline Land use classes & $\begin{array}{l}\text { Average } \\
\text { soil loss }\end{array}$ & $\begin{array}{c}\text { Standard } \\
\text { dev. }\end{array}$ & $\begin{array}{c}\text { Average } \\
\text { soil loss }\end{array}$ & $\begin{array}{c}\text { Standard } \\
\text { dev. }\end{array}$ & $\begin{array}{c}\text { Average } \\
\text { soil loss }\end{array}$ & $\begin{array}{c}\text { Standard } \\
\text { dev. }\end{array}$ & $\begin{array}{c}\text { Average } \\
\text { soil loss }\end{array}$ & $\begin{array}{c}\text { Standard } \\
\text { dev. }\end{array}$ & $\begin{array}{c}\text { General } \\
\text { average }\end{array}$ \\
\hline Badlands (degraded) & 355 & 20.12 & 349 & 197.42 & 323 & 199.49 & 307 & 184.75 & 333 \\
Cereal crops & 83 & 54.15 & 81 & 53.35 & 82 & 54.72 & 81 & 54.39 & 82 \\
Mixed farmlands & 65 & 45.85 & 64 & 46.11 & 65 & 43.69 & 68 & 45.36 & 66 \\
Olive trees & 71 & 43.87 & 78 & 49.43 & 80 & 46.25 & 79 & 46.86 & 77 \\
Reforestation & 73 & 37.54 & 70 & 39.77 & 73 & 39.55 & 71 & 37.35 & 72 \\
Protected forest & 61 & 21.09 & 58 & 19.54 & 61 & 18.77 & 61 & 20.49 & 60 \\
\hline
\end{tabular}

Tab. 2: Average soil loss by land cover using RUSLE ( $\left.\mathrm{Mg} \mathrm{ha}^{-1} \mathrm{yr}^{-1}\right)$

RUSLE Abschätzung des mittleren Bodenverlusts, nach Landnutzung ( $\left.M g \mathrm{ha}^{-1} \mathrm{yr}^{-1}\right)$

Perte de sol moyenne par occupation de sol selon RUSLE (Mg ha $\left.a^{-1} y r^{-1}\right)$

initiated rapidly if these zones are to remain viable for farming.

It should be emphasized that the results presented in this analysis only provide a relative spatial and temporal assessment of net soil loss within the study area. As RUSLE only assesses sheet wash and not channelized flow erosion, the results are only an approximation of reality, despite the likelihood that the contribution of the latter is minor (EL GAROUANI 


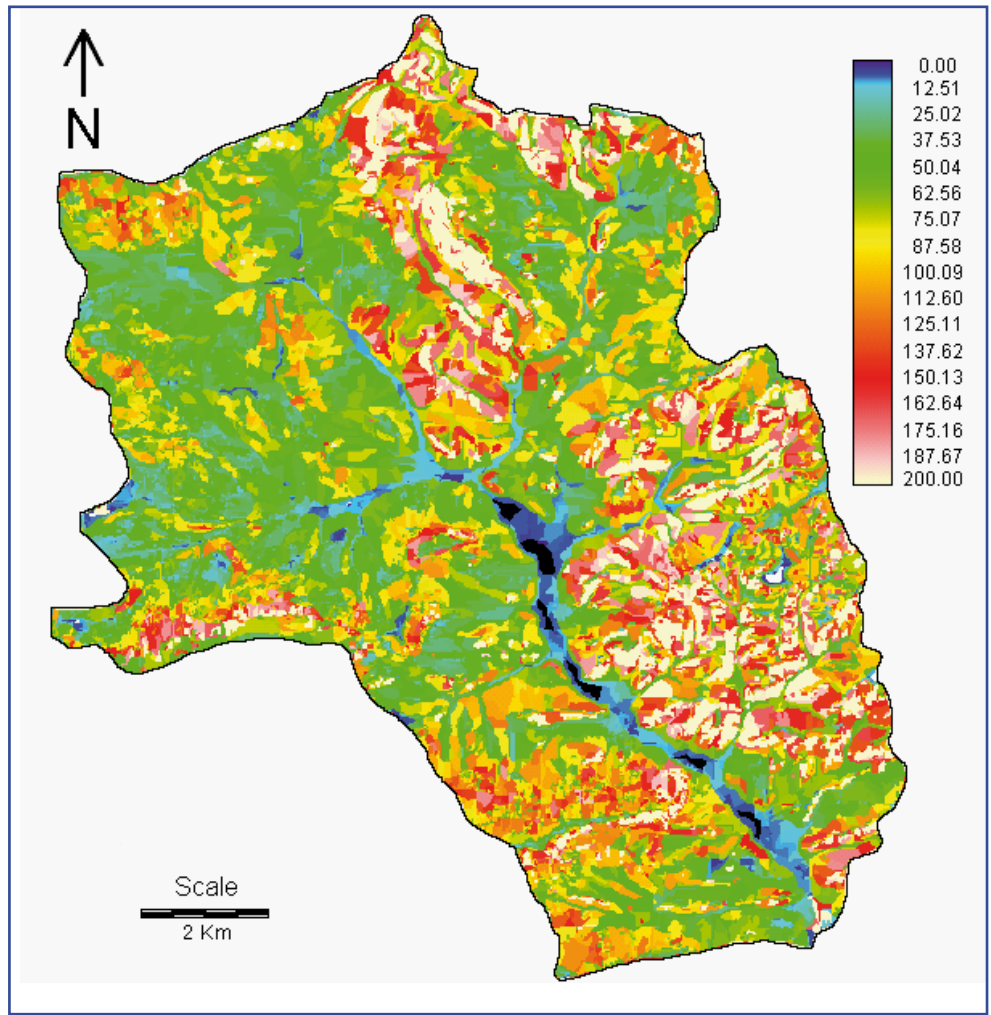

Fig. 5: RUSLE estimated soil loss ( $\left.\mathrm{Mg} \mathrm{ha}^{-1} \mathrm{yr}^{-1}\right)$

RUSLE Abschätzung des Bodenverlusts ( $\left.M g \mathrm{ha}^{-1} \mathrm{yr}^{-1}\right)$

Perte estimée de sol selon RUSLE (Mg ha $\left.a^{-1} r^{-1}\right)$

Cartography: H. Chen, A. El Garouani, L.A. Lewis, utilizing the Idrisi GIS software

et al. 2003). Thus, it is likely that the RUSLE/SEDIMENTATION module predictions are conservative in the badland areas where concentrated flows occur even though overland flows dominate in these areas too. Moreover, some factors that affect erosion have not been incorporated into the assessment. For example, the presence of stones on the surface in many areas was not included despite the likelihood that they could affect erosion rates. Further, the erosivity factor (R) was based on annual precipitation monitored near the mouth of the basin. The $\mathrm{R}$ values used for the whole basin were extrapolated from that point based on the basin's precipitation patterns. Actual measurements of $\mathrm{R}$ would improve the reliability of this factor.

In spite of these deficiencies, the method presented in this study produced valid insight into both the temporal and spatial patterns of erosion, erosion risk and sedimentation in the basin. With this approach, it was possible to identify zones which, in the long-term, are likely to experience excessively high soil losses and deposition.

\section{Conclusion}

This article presents a rapid approach to assessment of spatial and temporal patterns of soil loss and deposition utilizing remote sensing and GIS within the context of a stream basin in a Mediterranean region. It reports on the extension of the RUSLE model to permit net soil loss and depositional areas to be identified and assessed. This is considered of particular relevance where soil losses are transported beyond field boundaries. The results indicate that former studies in the area, which were neither sensitive to deposition nor concerned with the movement of the soil loss through 


\begin{tabular}{|c|c|c|c|c|c|c|c|c|c|}
\hline \multirow[b]{2}{*}{ Land use classes } & \multicolumn{2}{|c|}{1987} & \multicolumn{2}{|c|}{1994} & \multicolumn{2}{|c|}{2000} & \multicolumn{2}{|c|}{2002} & \multirow{2}{*}{$\begin{array}{r}1987-2000 \\
\text { General } \\
\text { average }\end{array}$} \\
\hline & $\begin{array}{l}\text { Average } \\
\text { soil loss }\end{array}$ & $\begin{array}{c}\text { Standard } \\
\text { dev. }\end{array}$ & $\begin{array}{l}\text { Average } \\
\text { soil loss }\end{array}$ & $\begin{array}{c}\text { Standard } \\
\text { dev. }\end{array}$ & $\begin{array}{l}\text { Average } \\
\text { soil loss }\end{array}$ & $\begin{array}{c}\text { Standard } \\
\text { dev. }\end{array}$ & $\begin{array}{c}\text { Average } \\
\text { soil loss }\end{array}$ & $\begin{array}{c}\text { Standard } \\
\text { dev. }\end{array}$ & \\
\hline Badlands (degraded) & ) 24 & 68.50 & 30 & 67.02 & 25 & 66.33 & 33 & 69.64 & 26 \\
\hline Cereal crops & -1 & 26.21 & -1 & 27.07 & -2 & 26.70 & -1 & 25.60 & -1 \\
\hline Mixed farmlands & -5 & 26.88 & -6 & 28.01 & -6 & 27.79 & -2 & 23.44 & -5 \\
\hline Olive trees & -0.1 & 22.25 & 0.6 & 26.67 & 0.8 & 18.78 & 0.6 & 18.44 & 0.5 \\
\hline Reforestation & 0.3 & 21.88 & -1 & 26.76 & -5 & 28.66 & 2 & 18.00 & -1 \\
\hline Protected forest & 1 & 15.40 & 1 & 13.31 & 2 & 14.26 & 2 & 13.81 & 2 \\
\hline
\end{tabular}

Tab. 3: Average net soil loss and deposition by land cover calculated using the SEDIMENTATION module (Mg $\left.\mathrm{ha}^{-1} \mathrm{yr}^{-1}\right)$ (negative values are deposition; positive values are soil loss; averages have been rounded) Mittlerer Nettobodenverlust und mittlere -ablagerung, nach Landnutzung, berechnet mit dem Modul SEDIMENTATION $\left(\mathrm{Mg} \mathrm{ha}^{-1} \mathrm{yr}^{-1}\right)$ (negative Werte bedeuten eine Ablagerung, positive einen Bodenverlust; Mittelwerte wurden gerundet) Pertes et dépôt nets de sol selon la couverture de sol selon le module SEDIMENTATION (Mg ha $\mathrm{yr}^{-1}$ ) (les valeurs négatives indiquent les dépôts; les valeurs positives indiquent les pertes; les moyennes ont été arrondies)

the area probably overestimated erosion in many areas, especially on the gentle slopes. In particular, deposition occurring along the valley bottoms was not identified.

The approach used allows for estimation of net soil loss/ deposition for any area within a catchment as well as for assessment of their spatial patterns. As the approach considers both soil loss and deposition, the results approximate reality to a greater degree than those determined by RUSLE alone. Although the accuracy of the soil loss and deposition values derived from the combined RUSLE/SEDIMENTATION module approach is open to discussion due to data limitations of the area, the method presented allows at the very least a rapid assessment of soil loss and deposition and a relative ranking of erosion and deposition within a study area.

With a basic data base such as that available for the study area and typical for many areas within developing countries, results gained from this approach can allow decision makers and developers to obtain a relative picture of existing conditions in any area and simulate land use/land cover scenarios in order to plan interventions to curtail erosion and deposition.

\section{References}

Al Karkouri, J. (2003): Dégradation du milieu naturel dans le bassin de Beni Boufrah (Rif Central Maroc): analyse des facteurs et des processus, essai de quantification et modélisation spatiale. - Thèse d'Etat, Université Mohamed V, Faculté des Lettres, Département de géographie, Rabat.

ArNoldus, H.M.J. (1980): Methodology used to determine the maximum average soil loss due to sheet and rill erosion in Morocco. - FAO (Food and Agriculture Organization of the United Nations) Soils Bulletin 34: 39-48.

BonN, F. (1998): La spatialisation des modèles d'érosion des sols à l'aide de la télédétection et des SIG: possibilités, erreurs et limites. - In: Science et Changements Planétaires/Sécheresse 9, 3:185-192.

Dhman, H. (1994): Utilisation des SIG et des télédétections dans l'étude de l'érosion hydrique: application au bassin versant de Tleta. - Mémoire du troisième cycle, Ecole Nationale Forestière d'Ingénieurs (ENFI), Rabat. Diallo, A.A. (2000): Intégration du modèle USLE dans un SIG pour la cartographie de l'érosion hydrique dans le bassin versant de Beni Boufrah (Rif central). - Mémoire du troisième cycle, Ecole Nationale Forestière d'Ingénieurs (ENFI), Salé, Maroc.

EAstman, J.R. (2006): Manual Idrisi Andes: Guide to GIS and image processing. - Worcester, MA: Clark University.

El Garouani, A., Merzouk, A., Jabrane, R. \& M.R. Boussema (2003): Cartographie de l'érosion des sols dans le bassin versant de l'Oued Jemâa (Prérif, Maroc). - In: Revue géomaghreb 1:39-46. 


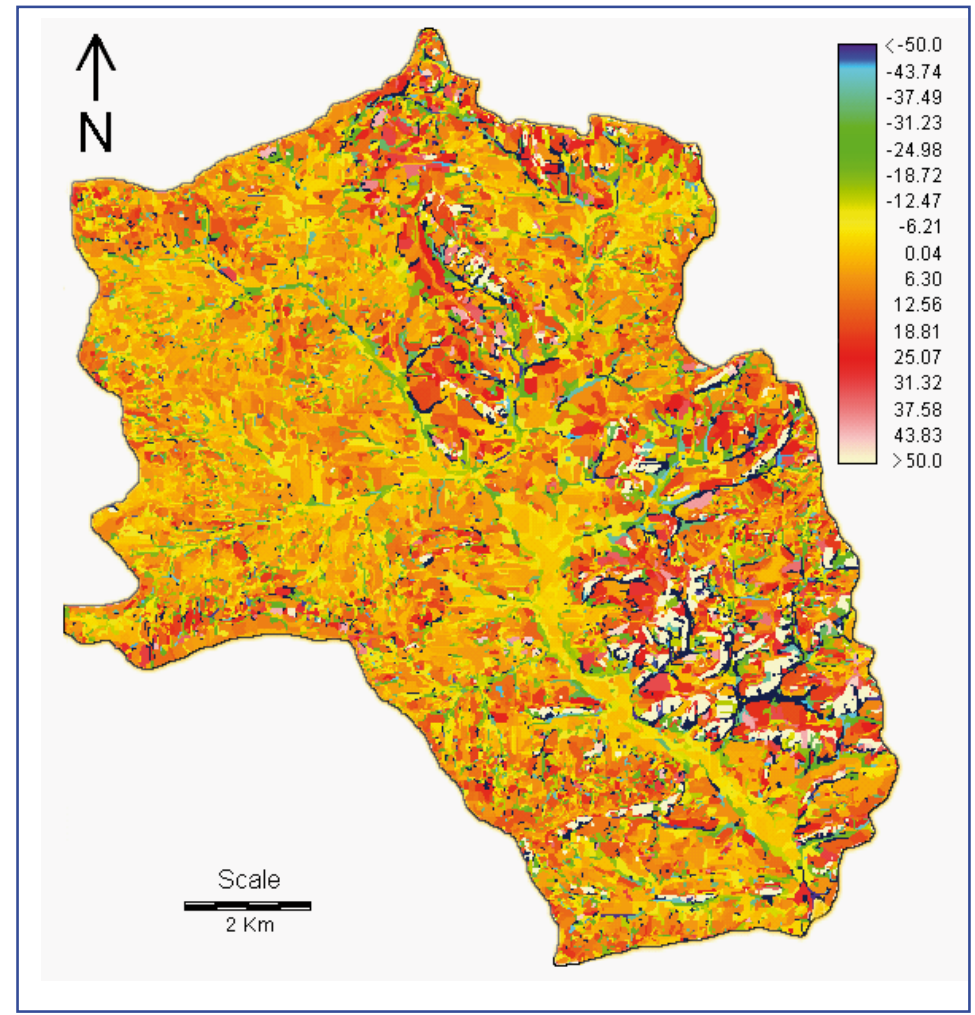

Fig. 6: SEDIMENTATION module estimated net soil loss (positive) and deposition (negative) ( $\left.\mathrm{Mg} \mathrm{ha}^{-1} \mathrm{yr}^{-1}\right)$ Mit dem Modul SEDIMANTATION geschätzter Nettobodenverlust (positiv) und-ablagerung (negativ) (Mg ha-1 $\left.y r^{-1}\right)$

Le module SEDIMENTATION a estimé la perte nette de sol (positive) et le dépôt (négatif) ( $M g h a^{-1} y r^{-1}$ )

Cartography: H. Chen, A. El Garouani, L.A. Lewis, utilizing the Idrisi GIS software

Fernandez, C., Wu,J.Q., McCool, D.K.\& C.O. Stockle (2003): Estimating water erosion and sediment yield with GIS, RUSLE, and SEDD. - In: Journal of soil and water conservation 58: 128-136.

Heusch, B. (1970): L'érosion dans le Prérif: une étude quantitative de l'érosion hydraulique dans les collines marneuses du Prérif occidental. - In: Annales des recherches forestières $12: 9-176$.

JAIN, A.K., MurTy, M.N. \& P.J. FLYNN (1999): Data clustering. - In: ACM computing surveys 31: 264-323.

Kalman, R. (1967): Essai d'évaluation pour le pré-Rif du facteur couverture végétale de la formule de Wischmeier de calcul de l'érosion. - In: Rapport pour l'administration de la forêt et d'eau, Rabat: 1-12.

Leblanc, D. (1979): Etude géologique du Rif externe oriental au Nord de Taza (Maroc). $-=$ Notes et mémoires 281, Service Géologique Marocain, Rabat:1-159. Lewis, L.A.,Verstraeten, G. \& H.Zhu (2005): RUSLE applied in a GIS framework: Calculating the LS factor and deriving homogeneous patches for estimating soil loss. - In: International journal of geographical information science 19: 809-829.

Mitasova, H., Hofierka, J., Zlocha, M. \& L.R. Iverson (1996): Modelling topographic potential for erosion and deposition using GIS. - In: International journal of geographical information science 10: 629-642.

Moore, I.D. \& G.J. Burch (1986): Modelling erosion and deposition: Topographic effects. - In: Transactions of the ASAE (American Society of Agricultural Engineers) 29: 1624-1640.

Mutua, B.M., KliK, A. \& W. Loiskandl (2006): Modelling soil erosion and sediment yield at a catchment scale: The case of Masinga catchment, Kenya. - In: Journa1 of land degradation and development 7:557-570.

Rahнou, M. (1999): L'érosion dans le Prérif central, zone interfluviale Leben-Sebou-Ouergha, un prolon- 
gement de l'évolution naturel, une production sociale. - Thèse d'Etat, Université Mohammed V, Faculté des Sciences, Laboratoire d'Hydrobiologie et Ecologie Générale, Rabat.

Rango, A. \& H.M.J. Arnoldus (1987): Aménagement des bassins versants. - In: Cahiers techniques de la FAO: $1-11$.

Renard, K.G., Foster, G.R., Weesies, G.A. \& J.P. PorTer (1991): RUSLE: Revised Universal Soil Loss Equation. - In: Journal of soil and water conservation 46: 30-33.

Renard, K.G., Foster, G.R., Weesies, G.A., McCool, D.K. \& D.C. Yoder (1997): Predicting soil erosion by water: A guide to conservation planning with the Revised Universal Soil Loss Equation (RUSLE). - = Agriculture handbook 703, U.S. Department of Agriculture, Washington, D.C.

TribaK, A. (2000): L'érosion hydrique en moyenne montagne du Prérif oriental (Maroc). Etude des agents et des processus d'érosion dans une zone de marnes tertiaires. - Thèse d'Etat, Université Chouaib Doukkali, Département de géographie, Al-Jadida, Maroc.

TribaK, A. (2002): Contraintes du milieu et fragilité d'un espace montagnard marocain: les montagnes du Prérif oriental. - In: Annales de géographie 625: 227245.

Tribak, A., El Garouani, A. \& M. Abahrour (2006): Cartographie et évaluation quantitative de l'érosion hydrique dans un espace montagnard marocain: cas du sous bassin versant de l'Oued Tleta, Prérif oriental. - In: Proceedings of the $14^{\text {th }}$ Conference of the International Soil Conservation Organization (ISCO), 1519 May 2006, Marrakech, Morocco: 1-10.

Van Rompaey, A., Verstraeten, G., Van Oost, K., Govers, G. \& J. Poesen (2001): Modelling mean annual sediment yield using a distributed approach. - In: Earth surface processes and landforms 26: 1221-1236. WischmeIER, W.H. (1976): Use and misuse of the universal soil loss equation. - In: Journal of soil and water conservation 31:5-9.

WischmeIER, W.H. \& D.D. Smith (1978): Predicting rainfall erosion losses - a guide to conservation planning. - = Agriculture handbook 537, U.S. Department of Agriculture, Washington, D.C.

\section{Summary: Modelling soil erosion and deposition within a Mediterranean mountainous environment utilizing remote sensing and GIS - Wadi Tlata, Morocco}

This article presents the results of the GIS-based analysis of four Landsat and Spot images covering a fifteen year period $(1987,1994,2000,2002)$. The purpose of the study was to establish a means of rapidly determining land cover and land use changes, as well as spatial patterns of erosion and deposition, in areas with relatively poor data bases and where soil loss results primarily from nonchannelized flows. The procedure selected involved the following: establishment of land use class distribution and size for each year of observation, static estimation of soil loss, calculation of net erosion and deposition, and prioritisation of critical areas. Thus, for the targeted $123 \mathrm{~km}^{2}$ Tlata catchment of northeastern Morocco, six main land use classes could be defined (highly degraded lands, annual cereal crops fields, mixed farmlands, olive trees, reforested areas, and natural protected forest). Analysis of remote sensing data allowed establishment of the areal distribution of each land use class for each year. Soil loss was estimated using a RUSLE module integrated in a GIS framework. These static areal estimates of soil loss were then fed into a sedimentation algorithm that models downslope movement of soil loss. From the resulting spatial (flow) movements, net erosion and deposition for each time period could be estimated. The results permit, at the least, an ordinal ranking of erosion and deposition within the basin. This supports decision-making processes on prioritization of areas where interventions are needed to ameliorate or prevent land degradation.

Keywords: erosion, land degradation, modelling, GIS, remote sensing, RUSLE

Résumé: Modélisation de l'érosion et de la déposition du sol dans un environnement montagneux méditerranéen: l'apport de la télédétection et des SIG à Wadi Tlata, Maroc

Dans cette étude, quatre images des satellites Landsat TM et Spot HRV ont été traitées et analysées dans un SIG pour une période de quinze ans (1987, 1994, 2000, 2002). Le but de cette étude était d'illustrer la possibilité de déterminer rapidement le changement de l'occupation et de l'utilisation du sol ainsi que la spatialisation des modèles de l'érosion et de la déposition dans un secteur avec peu de données et dont les pertes de sol sont essentiellement en nappe. La procédure adoptée est la suivante: établissement de la distribution et de la taille relative à l'utilisation du sol, estimation statique des pertes de sol, calcul de l'érosion et de la déposition nettes, établissement de priorités pour les aires critiques. L'analyse de données satellitaires a permis d'identifier six principaux types d'occupation du sol (terrains fortement dégradés, céréaliculture, mélange de céréaliculture et d'arboriculture, oliviers, reboisement et forêt claire protégée) dans le bassin versant de l'Oued Tlata d'une superficie de $123 \mathrm{~km}^{2}$, situé au nord-est du Maroc. Après la cartographie de l'occupation du sol pour chaque date de prise de vue, les pertes de sol ont été estimées par le module RUSLE (Revised Universal Soil Loss Equation) intégré dans un SIG. Ces évaluations spatiales statiques des pertes de sol ont été ensuite utilisées dans un algorithme de sédimentation qui modélise le mouvement de ces pertes en sol vers l'exutoire. Ces mouvements 
spatiaux ont été alors évalués pour estimer l'érosion et la déposition nettes pour chaque période. Les résultats obtenus permettent la classification rapide de l'érosion et de la déposition à l'échelle du bassin et l'identification des secteurs où les interventions sont nécessaires pour lutter contre la dégradation des sols.

Mots-clés : érosion, dégradation des sols, modélisation, SIG, télédétection, RUSLE

\section{Zusammenfassung: Modellieren von Bodenabtrag und Ablagerung innerhalb eines Berggebietes in einer mediterranen Umgebung unter Anwendung von Fernerkundung und GIS - Wadi Tlata, Marokko}

Dieser Artikel präsentiert die Resultate einer GISbasierten Bearbeitung und Analyse von vier Landsatund Spot-Bildern, welche über einen Zeitraum von 15 Jahren aufgenommen wurden $(1987,1994,2000,2002)$. Das Ziel der Studie war es, die Möglichkeit einer schnellen Bestimmung von Land- und Bodennutzung zu zeigen, ferner auch das Erstellen von räumlichen Mustern der Abtragung und Ablagerung. Dies sollte in Sektoren mit relativ wenig vorhandenen Daten gezeigt werden, in welchen der Bodenverlust hauptsächlich als Folge von nicht-kanalisiertem Abfluss hervorgeht. Analysen der Satellitendaten ermöglichen im Einzugsgebiet der Tlata, welches $123 \mathrm{~km}^{2}$ misst und sich im Nordosten Marokkos befindet, sechs Hauptlandnutzungsklassen zu identifizieren (stark beschädigte Gebiete, Getreidefelder, gemischter Anbau, Olivenhaine, aufgeforstete Gebiete, natürlich geschützte Wälder). Nach der Einteilung der Gebiete in die verschiedenen Landnutzungsklassen für jedes aufgenommene Jahr wurde der Bodenverlust durch das in IDRISI integrierte RUSLE (Revised Universal Soil Loss Equation) Modul geschätzt. Der in den Testgebieten ermittelte Bodenverlust wurde mit einem Sedi- mentationsalgorithmus gekoppelt. Die räumlichen Muster von Erosion und Ablagerung wurden addiert, um den Nettoabtrag für jeden Zeitraum zu schätzen. Die erhaltenen Resultate erlauben, eine Klassifizierung der Abtragung und Ablagerung im Massstab des Einzugsgebietes zu erstellen und die Bereiche zu identifizieren, in welchen Massnahmen zur Verbesserung der Situation oder zur Prävention einer schlechten Landnutzung ergriffen werden müssen.

Schlüsselwörter: Erosion, Landdegradierung, Modellierung, GIS, Fernerkundung, RUSLE

Hao Chen, Research Associate, Clark Labs, Clark University, Worcester, Massachusetts 01610-1477, USA. e-mail: hchen@clarku.edu

Dr. Abdelkader El Garouani, Laboratoire de Géosciences et Environnement, FST de Fès, Université Sidi Mohamed Ben Abdellah, B.P. 2202, Fès, Maroc.

e-mail: el_garouani@yahoo.fr

Prof. Dr. Laurence A. Lewis, Graduate School of Geography, Clark University, Worcester, Massachusetts 016101477, USA.

e-mail: llewis@clarku.edu

\section{Manuskripteingang/received/manuscrit entré le} 25.9.2007

Annahme zum Druck/accepted for publication/accepté pour l'impression: 1.3.2008 